\title{
TAF1 Gene Mutation
}

National Cancer Institute

\section{Source}

National Cancer Institute. TAF1 Gene Mutation. NCI Thesaurus. Code C153519.

A change in the nucleotide sequence of the TAF1 gene. 